\title{
Sama wśród mężczyzn. Zofia Nałkowska jako instytucja życia literackiego w międzywojennej Polsce
}

Kiedy po roku 1918 rozpoczął się proces instytucjonalnej odbudowy państwa polskiego, środowisko literackie niezwłocznie się weń włączyło. Aktem inicjatorskim działań zmierzających do profesjonalizacji twórczości pisarskiej stał się Projekt Akademii Literatury Polskiejautorstwa Stefana Żeromskiego. W topice jego wypowiedzi wątki laudacyjne przeplatają się z lamentacyjnymi, co uwidacznia się już w pierwszych akapitach:

Literatura - sztuka pisarska, której dorobek był, jest i będzie własnością społeczeństwa, zasobem duchowym narodu, pokarmem intelektualnym pokoleń, wciąż narastającym skarbem przyszłości, przede wszystkim i na wsze strony okazywanym tytułem do bytu politycznego wiecznej i całej rzeczypospolitej ducha - nie doznawała ongi w Polsce i nie doznaje dziś poparcia ani opieki w żadnym z poszczególnych momentów swego fermentu i krystalizacji. Literatura polska żyje swoim porządkiem, jak może i umie, a raczej słania się i wałęsa własnymi drożynami, ścieżkami i bezdrożami. Trudno pomocą i poparciem jej nazywać sakiewkę króla czy magnata, z łaski pańskiej, w chwili dobrego usposobienia rzuconą niegdyś nadwornemu śpiewakowi - dzisiejszą nagrodę pieniężną, dożywocie na folwarku po dwudziestu pięciu latach samoistnych trudów oraz wysoki, nadzwyczaj wysoki katafalk i karawan Wyspiańskiego lub Witkiewicza ${ }^{\mathrm{T}}$.

Do wystąpienia w takiej roli i w takiej tonacji miał Żeromski szczególne prawo, gdyż legitymizował go los klepiącego niegdyś biedę młodego literata o wielkich ambicjach, który dzięki

I S. Żeromski, Projekt Akademii Literatury Polskiej, Warszawa-Kraków 1918, s. 5-6, http: / / www.polona.pl/dlibra $/$ doccontent? $\mathrm{id}=32488 \&$ from $=$ FBC [dostęp: 20 listopada 2012]. 
artystycznej wielkości i społeczno-patriotycznej wartości dzieł zyskał powszechne uznanie, status pisarza narodowego i zabezpieczenie materialne dla siebie oraz swojej rodziny. Sednem przedstawionego przezeń projektu było stworzenie formalnej struktury, która pełniłaby dwie zasadnicze funkcje: państwowego mecenatu i związku zawodowego. Argumentację Żeromskiego można sprowadzić do następującego sylogizmu: literatura piękna to „sztuka najbardziej czynna, z życiem tajemną pępowiną zrośnięta, pulsująca od uczuć, sztuka [...] wciąż stająca się, zawsze nowa, nie ustalona"; literatura polska nie dysponuje żadnym instytucjonalnym narzędziem, które tę jej niezwykłość by sankcjonowało, tudzież w sposób wymierny kultywowało ergo - w wolnej Polsce należy jak najszybciej instytucję takową powołać. W wizji autora Popiołów miałaby ona skupić działalność na trzech sprawach: „czystości i piękności języka polskiego” (tu warto podkreślić, że wielką wagę przykładał Żeromski do prac translatorskich), „rozszerzenia kultury literackiej na warstwy szerokie inteligencji i ludu” oraz ,instancji i obrony twórczości wolnej” ${ }^{2}$. W praktyce jednak miało się stać tak, że każdy z tych celów okazał się priorytetowy dla innych obszarów zinstytucjonalizowanej kultury literackiej międzywojnia. Najwcześniej, bo już od początku lat 20., zaczął się aktywizować w środowiskach literackich ruch związkowy, gdyż idea obrony zawodowych interesów pisarzy i pisarek była najbardziej nośna i jednocząca. Po założeniu podczas Zjazdu Literatów Polskich w roku 1920 warszawskiego oddziału Związku Zawodowego Literatów Polskich, z Żeromskim jako pierwszym jego prezesem, ruszyła fala inicjatyw lokalnych i pod koniec dwudziestolecia niezależne stowarzyszenia pisarskie istniały już w każdym znaczącym ośrodku życia kulturalnego II Rzeczypospolitej. W osobnych strukturach zrzeszali się poza tym autorzy i kompozytorzy sceniczni (ZAiKS), dziennikarze i inni ,pracownicy pióra”. Zadania „krzewicielskie" i oświatowe w przeważającej mierze pozostawały w gestii władz państwowych, zwłaszcza Ministerstwa Wyznań Religijnych i Oświecenia Publicznego, w ramach którego funkcjonował departament (w ówczesnej nomenklaturze „referat”) literatury i sztuki. O zagraniczne kontakty literackie zabiegał polski Pen Club, utworzony również dzięki staraniom Żeromskiego. Natomiast powołana w końcu do życia w roku 1933 Polska Akademia Literatury miała opiekować się piśmiennictwem narodowym oraz pracę nad jego rozwojem, co zwięźle sformułowano w artykule drugim statutu. Artykuł piąty precyzował sposoby wyko-

\footnotetext{
${ }^{2}$ Ibidem, s. 9.
} 
nywania tych zadań w następujących punktach: reprezentowanie przez PAL polskiego piśmiennictwa artystycznego w stosunku do władz; wypowiadanie opinii w sprawach języka, kultury i literatury polskiej; przyznawanie nagród i stypendiów; podejmowanie wydawnictw poświęconych rozwojowi polskiej sztuki literackiej³ . Pierwszych siedmiu członków mianowali wspólnym aktem Prezes Rady Ministrów i Minister WRiOP, a następnie tak wyłoniony areopag wybierał pozostałych ośmiu.

Gdy kończyła się Wielka Wojna i zaczynała II Rzeczpospolita, Zofia Nałkowska znalazła się w jednym z przełomowych momentów swojego życia osobistego, po definitywnym rozpadzie małżeństwa $\mathrm{z}$ Leonem Rygierem wchodziła właśnie $\mathrm{w}$ miłosną relację z Janem Jurem-Gorzechowskim - postacią otoczoną nimbem żołnierza bohatera i legendą wspólnej walki po stronie Józefa Piłsudskiego. Ten związek dwóch potężnych i niezależnych osobowości od początku był naznaczony konfliktem interesów - Gorzechowski, po pierwszej fascynacji wybitną już wtedy i uznawaną literatką, chciał mieć za żonę kobietę reprezentacyjną, ale uległą i podporządkowaną priorytetom mężowskim, Nałkowska zaś, pierwotnie oczarowana władczą męskością kochanka, szybko rozpoznała tkwiące w niej zagrożenia dla jej kobiecej i twórczej podmiotowości, nie miała też zamiaru rezygnować ze swej pisarskiej kariery. Dla rozwoju tej ostatniej zawsze niezbędne w jej przypadku były intensywne kontakty $\mathrm{z}$ innymi ludźmi pióra i intelektu, wyrażające się w ważnych, tworzących bliskość rozmowach, publicznych dyskusjach oraz wspólnych działaniach. Życie było dla Nałkowskiej tworzeniem i kultywowaniem pozostającej $\mathrm{w}$ nieustannym ruchu sieci relacji interpersonalnych, a choć w jej antropologii człowiek człowiekowi na ogół zgotowywał los nie do pozazdroszczenia, to jednak więź międzyludzka pozostawała od początku do końca podstawowym tematem tak jej pisarstwa, jak egzystencji własnej.

O tym, jak intensywny był to okres w życiu Nałkowskiej, świadczy nieregularność zapisków diarystycznych - między ostatnim z 1919 a pierwszym z 1920 upłynął cały rok. Pisarka od początku angażowała się $\mathrm{w}$ tworzenie instytucjonalnych struktur literackich. 24 czerwca 1920 r. notuje:

Przez ostatnie miesiące wykazałam „zdolność do czynu”, organizując Zjazd Literatów. W pracy tej nie miałam żadnych złudzeń

3 Rozporządzeniem Rady Ministrów z 9 września 1933 r., ogłoszonym w „Monitorze Polskim” 11 października 1933 r., Sejm natomiast podjął uchwałę o PAL dopiero 2 lipca 1937 r. - zob. M. Rusinek, Moja wieża Babel, Warszawa 1982, s. 13. 
i nie doznałam żadnych zawodów. Żadna z towarzyszących takiemu działaniu przykrości nie zniechęciła mię do ludzi; wszystko uważałam za zgodne z prawami życia. [...] Ostatnio pracuję w wynikłym z owego Zjazdu Związku Zawodowym4.

Udzielała się także w komisji stypendialnej Ministerstwa Wyznań Religijnych i Oświaty Narodowej, gdzie wraz z Leopoldem Staffem i Juliuszem Kadenem-Bandrowskim i innymi podejmowała decyzje o tym, który z literatów otrzyma wsparcie materialne ze strony państwa. Warto $\mathrm{w}$ tym miejscu podkreślić, że $\mathrm{w}$ pierwszych latach istnienia II Rzeczypospolitej różnice ideowe i światopoglądowe nie przesądzały o dystrybucji dóbr i przywilejów w świecie literackim, jak zaczęło się to dziać w drugiej dekadzie międzywojnia, toteż nawet „antypaństwowi” twórcy niejednokrotnie otrzymywali ministerialne stypendia, choć taka polityka miała oczywiście swoje drugie dno. Michał Rusinek pisze o owej komisji, że „ «wazeliniarze» byli lekceważeni, o wiele większe szanse mieli buntujący się lub zbuntowani, bo takich chciano mieć na swoim utrzymaniu" ${ }^{5}$. Dzięki takiemu podejściu władz pomoc finansową uzyskali między innymi Adam Polewka, Elżbieta Szemplińska, Wanda Wasilewska czy Wacław Kowalski.

Pracując na rzecz środowiska literackiego, Nałkowska sama stawała się w międzywojniu literacką instytucją. Z rytmu tej pracy wytrąciło ją na lat kilka małżeństwo z Gorzechowskim i przeprowadzka do Grodna, gdzie tenże pełnił - niezbyt wysoką jak na towarzysza broni Piłsudskiego - funkcję dowódcy żandarmerii. Również model matrymonium, jakiemu hołdował Gorzechowski - dominujący mąż, uległa i reprezentacyjna żona - nie sprzyjał formom aktywności towarzyskiej, jakich autorka Choucas najbardziej łaknęła i potrzebowała dla rozwoju swojej osobowości i swojego talentu. Rzec można, iż szczęśliwie dla polskiej literatury oraz międzywojennych kręgów literackich związek ten nie trwał długo i już w połowie lat 20. Nałkowska znalazła się $\mathrm{z}$ powrotem $\mathrm{w}$ Warszawie, zaś lata 30 . przyniosły apogeum jej wielkości pisarskiej i znaczenia jako osobistości publicznej. We wstępie do Dzienników 1930-1939 Hanna Kirchner pisze, że wyłania się z nich

${ }_{4}$ Z. Nałkowska, Dzienniki III 1918-1929, oprac., wstęp i komentarz H. Kirchner, Warszawa 1980, s. 64-65. Oprócz niej w działalność związkową angażowały się też inne kobiety piszące, we władzach ZZLP znalazły się np. Herminia Naglerowa i Maria Kuncewiczowa. Ta ostatnia była również aktywną działaczką Pen Clubu.

5 M. Rusinek, Opowieści niezmyślone, Kraków 1969, s. 183. 
obraz działań w instytucjach literackich: w Związku, PEN-Clubie, PAL-u, więc protesty, podpisy, nagrody, stypendia dla „zdychającej z głodu młodej literatury”, reprezentacja, referaty kongresowe i przy tej okazji strzępy wiadomości o samopoczuciu literatury europejskiej na skraju wojny, w cieniu totalitaryzmów. Jest tu też widoczna szczególna oboczność kultury oficjalnej, obecnej w rządowych salonach i na rautach w ambasadach (także i w radzieckiej!) czy w sali recepcyjnej Akademii Literatury, i tej drugiej, powiedzmy: off-kultury, której znakami są w tym dzienniku np. Zespół „Przedmieście”, pismo „Studio” i rewizja rzeczy Kuczyńskiego w mieszkaniu Nałkowskiej, poeta Pasternak siedzący za komunizm w Berezie Kartuskiej, wizyty redaktora „Oblicza Dnia” i „Dziennika Popularnego", Mieczysława Bibrowskiego, i cuchnące nędzą i wilgocią rękopisy przychodzących po ocenę i pomoc debiutantów ${ }^{6}$.

Oboczność, o której wspomina Kirchner, znajdowała odbicie również w materialnej sytuacji samej Nałkowskiej. Pisarka od lat samodzielnie utrzymywała z pracy literackiej siebie, a zazwyczaj również swoich domowników; nawet w małżeństwie z Gorzechowskim ponosiła sporą część wydatków domowych. Jej budżet zawsze był mocno napięty, właściwie tylko w okresie krajowych i zagranicznych sukcesów teatralnych Domu kobiet (początek lat 30.) miewała jako taką swobodę finansową. Częściej jednak $\mathrm{z}$ trudem przychodziło jej wiązać koniec z końcem, co zmuszało ją do upokarzających kalkulacji i negocjacji z wydawcami. $\mathrm{Na}$ zewnątrz prezentowała się zawsze okazale, majestatycznie i strojnie, nieustannie była obecna w centrum życia publicznego, dlatego postrzegana była jako osoba majętna i wpływowa.

Prawdą jest, że na pomoc ze strony Nałki liczyć mogli zwłaszcza młodzi pisarze i fakt ten stanowił - stanowi do dziś - przyczynę niewybrednych komentarzy; z pisarkami łączyły ją więzi słabsze, aczkolwiek zawsze przyglądała się twórczości koleżanek po piórze z zaciekawieniem i aprobatą. O tym, jak kształtowały się jej relacje z Choromańskim, Schulzem, Rudnickim, Łaszowskim, wreszcie z kolejną „niedobrą miłością”, czyli Bogusławem Kuczyńskim, miałam okazję już pisać wcześniej7. Tu chciałabym tylko podkreślić, że mimo romansowych czy tylko flirtowych podtekstów - lub, jak woleliby może inni interpretatorzy jej ży-

${ }^{6}$ Z. Nałkowska, Dzienniki 1930-1939. Część 1 (1930-1934), oprac., wstęp i komentarz H. Kirchner, Warszawa 1988, s. 17.

7 E. Kraskowska, Natkowska i Schulz, Schulz i Natkowska, w: Osoba w literaturze $i$ komunikacji literackiej, red. E. Balcerzan, W. Bolecki, Warszawa 2000, s. 186-201. Przedruk w: eadem, Czytelnik jako kobieta, Poznań 2008, s. $166-191$. 
cia, dzięki nim - wsparcie zyskiwali na ogół autorzy wybitni, których dzieła w większości przetrwały próbę czasu, a niekiedy, jak w przypadku prozy Brunona Schulza czy Witolda Gombrowicza $^{8}$, osiągnęły rangę arcydzieł. Przyjaźnie te miały wymiar przede wszystkim intelektualno-artystyczny, dzięki nim dokonywała się wymiana myśli, wzajemna ocena dorobku twórczego, przekazywanie impulsów artystycznych, czego efekty można śledzić zarówno w utworach młodych podopiecznych Nałkowskiej, jak i w jej własnych książkach. „O nich to się mówiło pisał o sobie i swoich kolegach Tadeusz Breza - że chodzą na Nałkowską, kończą, jak gdyby o jakichś wykładach. Albo nawet wprost o tym czy innym z tej młodzieży, że jest na pierwszym czy na drugim roku Nałkowskiej" ${ }^{9}$. Hanna Kirchner po latach podsumuje: „Ta dojrzała kobieta ma tyle atutów, że może jak mężczyzna, niemłody, lecz błyszczący sukcesem, przyjmować lub odrzucać wedle swojej woli i przyciągać młodość" o. To jednak nie do końca prawda, raczej zewnętrzny pozór, gdyż Nałkowska nie jest wybierającą, tylko wybieraną. Jej zaangażowanie uczuciowe to zawsze następstwo cudzej miłości, cudzej adoracji, które w efekcie przeradza się w zależność. Taki jest bowiem nieubłagany mechanizm „niedobrej miłości”, wielokrotnie analizowanej przez pisarkę nie tylko w powieści o tym tytule i znanej jej dogłębnie z autopsji. Poza tym nawet dzisiaj trudno sobie wyobrazić, by dominujący, wysoko usytuowany w hierarchii społecznej mężczyzna pięćdziesięcioletni znosił ze strony swoich młodych kochanek takie niemiłe zachowania, jakie świadomej swego wiotczejącego ciała Nałkowskiej fundował najpierw chimeryczny Michał Choromański, a następnie wiecznie ją tyranizujący swoją zazdrością i pretensjami Bogusław Kuczyński...

Rok 1933 przyniósł autorce Granicy członkostwo w Polskiej Akademii Literatury. Jeszcze przed zaszczytnym powołaniem do tego gremium, w którym zresztą do końca jego trwania pozostawała jedyną kobietą, $\mathrm{w}$ sierpniu notowała $\mathrm{w}$ dzienniku:

${ }^{8}$ Gombrowicz tak wspomina Nałkowską: „[...] w tym właśnie najbardziej się lubowała - w wywąchiwaniu talentu, wyszukiwaniu wartości, choćby takich, co to nie dojrzysz bez lupy. [...] ona odkryła Schulza, utorowała drogę Rudnickiemu, poparła Piętaka, mnie też nie odmówiła pomocy i rady - nic dziwnego, że młodzież garnęła się do niej. Ona też garnęła się do młodzieży, będąc przy swoich latach zdumiewająco żywotna, wzbudzając zazdrość innych kobiet, które mówiły z przekąsem - Literatura konserwuje...”. W. Gombrowicz, Wspomnienia polskie. Wędrówoki po Argentynie, Paryż 1977. Cyt. za: Z. Nałkowska, Dzienniki IV 1930-1939. Czesść 2 (1935-1939), oprac., wstęp i komentarz H. Kirchner, Warszawa 1988, s. 14.

9 T. Breza, Wspomnienie o „Węztach życia”, w: Wspomnienia o Zofii Natkowskiej, red. W. Barcikowski, Warszawa 1965, s. 97.

to H. Kirchner, Natkoweska albo życie pisane, Warszawa 2011, s. 404. 
Załatwiam cudze sprawy, nie umiejąc poradzić własnym. [...] Jak się obronić od wszystkich dzikich żądań ludzkich - listów, telefonów, odezw, wywiadów, rozmów, rad, Związku, PEN-Clubu, całego świństwa tej literackiej polityki, w której nie mam siły zachować siebie. Nie chcę walczyć, ale mną walczą, co chwila okazuje się, że czemuś wbrew woli służę... ${ }^{\text {II }}$.

Polska Akademia Literatury miała się okazać instytucją w dużej mierze fasadową, sprowadzoną przede wszystkim do funkcji reprezentacyjnych i opiniodawczych. Pozbawiona odrębnego budżetu i własnych środków finansowych, zajmowała się głównie wybieraniem kandydatów do stypendiów i nagród literackich oraz przyznawaniem honorowych odznaczeń w postaci Złotego Wawrzynu i Srebrnego Wawrzynu, przez akademików zwanych protekcjonalnie „bobkami”. Poza tym odgrywała rolę oficjalnego salonu literackiego Warszawy, organizując w swojej siedzibie uroczyste zebrania publiczne - z prelekcjami wygłaszanymi przez członków, na które zapraszano po kilkaset osób, a także mniejszej rangi i o skromniejszym audytorium spotkania, dyskusje i odczyty - w których uczestniczyli nie tylko twórcy i humaniści, ale również przedstawiciele innych dziedzin, na przykład gospodarki czy wojskowości ${ }^{12}$. Zgodnie z własnym postanowieniem akademicy zbierali się trzy razy w miesiącu, przy czym dla tak dużej częstotliwości owych zebrań nie bez znaczenia był fakt, że za każde przysługiwała obecnym wysoka dieta, dla niektórych jak dla Nałkowskiej - będąca w pewnych okresach życia jedynym stałym źródłem dochodów. W każdym razie wszyscy poza krakowianinem Karolem Hubertem Rostworowskim pilnie na te posiedzenia uczęszczali, choć ich program, ustalany przez Juliusza Kadena-Bandrowskiego jako sekretarza generalnego, bywał niekiedy mocno naciągany. O tym, jak dużą wagę przywiązywała pisarka do finansowego aspektu członkostwa w PAL, świadczy poniżej cytowany wpis z podróży do Edynburga na kongres Pen Clubów, jaką w czerwcu 1934 r. odbywała delegacja polska:

Oto dylemat: jeżeli wrócę statkiem, nie zdążę na posiedzenie Akademii, stracę sto albo dwieście czy trzysta złotych i nie zdobędę subwencji dla moich „protegowanych”. Jeżeli pojadę koleją, to bilety i wizy będą droższe o tyle, że nie tylko nie zyskam na żetonach Akademii, ale po prostu nie wystarczy mi pieniędzy (w tej chwili mam, na polską walutę przeliczając, $470 \mathrm{zł})^{\mathrm{x} 3}$.

II Z. Nałkowska, Dzienniki IV 1930-1939. Część I (1930-1934), oprac., wstęp i komentarz H. Kirchner, Warszawa 1988, s. 377-378.

${ }_{{ }_{12}}$ Zob. M. Rusinek, Moja wieża Babel, s. 27-29.

I3 Z. Nałkowska, Dzienniki IV 1930-1939. Część I (1930-1934), s. 472. 
Gdy w nieformalnych literacko-osobistych kontaktach Nałkowską otaczali mężczyźni dużo od niej młodsi, w PAL miała do czynienia $\mathrm{z}$ rówieśnikami lub dużo starszymi kolegami, a swoje z nimi spory i starcia wielokrotnie komentowała w diariuszu. I tam jednak ciągnęły się za nią wątki romansowe - spośród owych kilkunastu dostojników rodzimej literatury dwóch swego czasu okazywało jej miłosne względy: Jan Lorentowicz i Karol Irzykowski. Z tym ostatnim nie miała lekkiego życia, aż do swej śmierci prześladował ją bowiem wrogością odrzuconego adoratora i domaganiem się zwrotu jakowychś dawno napisanych listów. Przede wszystkim jednak PAL przysporzyła pisarce kolejnych obowiązków i zajęć. O tym, jak w połowie lat 30. mogła wyglądać jej codzienność, da nam pojęcie wpis z 2 marca 1934 r., rekapitulujący wydarzenia kilkunastu dni $\mathrm{z}$ lutego. Oddaje on doświadczaną podówczas przez autorkę Granicy „akcelerację życia" ${ }^{{ }^{4}}$, a zarazem oświetla niektóre aspekty związków między literaturą i polityką w II Rzeczypospolitej, warto więc przy nim na chwilę się zatrzymać.

Ośrodkiem wydarzeń odnotowanych na tych stronicach są przygotowania do wręczenia przez PAL literackiej nagrody młodych pierwszemu jej laureatowi, Michałowi Choromańskiemu, i wybieranie umeblowania do nowo pozyskanej siedziby Akademii w dawnym pałacu Potockich. Ale to tylko, rzec można, lejtmotyw harmonogramu Nałkowskiej. Zapis obejmuje dni od 17 do 28 lutego, został sporządzony na podstawie czynionych naprędce notatek (inaczej nie byłoby możliwe odtworzenie natłoku oficjalnych i prywatnych spotkań, rozmów bezpośrednich i telefonicznych, tłumu ludzi, którzy się w tym krótkim czasie przez jej życie przewinęli). Takie pisanie „w biegu” było stałym zwyczajem pisarki i chciałoby się móc ją podejrzeć przy tej czynności ${ }^{15}$. Czy przysiadała przy jakichś przypadkowych stolikach? Czy robiła to w obecności innych osób? A może - dajmy się niestosownie ponieść wyobraźni - zdarzało jej się notować w „tezolku”, jak nazywała miejsce ustronne? Fragment zredagowany

${ }^{\text {I4 }}$ Ibidem, s. 408. Cały wpis obejmuje strony 408-418 cytowanego wydania dzienników i do nich się odwołuję w następnych przytoczeniach.

${ }_{5}$ Notatki takie stanowią osobny zbiór w rękopisach dziennika Nałkowskiej. Ich „materialność” opisuje Paweł Rodak następująco: „Notatki do dziennika z różyych epok to notatki dokonywane na gorąco, pośpieszne, niewyraźne, brudnopisowe; pisane na luźnych kartkach, na podłużnych paskach papieru, na kartkach postrzępionych lub pourywanych; $\mathrm{w}$ większości są to zapisy ołówkiem, często pomieszane $\mathrm{z}$ bardzo powszednimi zapiskami, takimi jak telefony, adresy etc.; część tych kartek jest włożona w ciemnoczerwoną okładkę [...]”. P. Rodak, Między zapisem a literaturą. Dziennik polskiego pisarza w XX wieku, Warszawa 2011, s. 297, przyp. 71. 
został stylem telegraficznym, który często się pojawia w dzienniku Nałkowskiej, ale tu osiągnął szczególną kondensację; równoważniki zdań i krótkie zdania pojedyncze spiętrzają się i napierają na siebie, wywołując efekt gonitwy zdarzeń i myśli, a przede wszystkim - ludzkiego tłoku. Jak zauważył Paweł Rodak, analizując fragment dziennika opisujący dwa kolejne posiedzenia PAL, dla diarystki ważne jest, „kto i jak mówi, jak wygląda, jak się zachowuje, ale nie - co mówi. Jest wyraźnie uwrażliwiona nie na słowa, ale na osobę, nie na werbalny komunikat, ale na wrażenie, jakie druga osoba robi na innych" ${ }^{16}$. Istotnie, często dowiadujemy się o ogólnym wrażeniu z rozmowy z kimś znajomym lub obcym, lecz nie otrzymujemy żadnej informacji o jej treści. Na przykład: „Wieczorem [...] u Dakowskiego, rozmowa $\mathrm{z}$ nim - mimo jego niemowlęcego wieku - osiąga zawrotne wyżyny”. Albo: „Rozmowa. Berent jest taki sam, jak w czasach, gdy go uwielbiałam - tylko siwy”. I jeszcze: „Po południu Karol i jego kłopoty".

Podczas tych kilkunastu dni lutego 1934 r. Nałkowska spotykała mnóstwo ludzi na przyjęciach (np. u pani Beckowej, w poselstwie sowieckim, u Wańkowiczów), na posiedzeniach PAL, Pen Clubu i ZZLP, w Ziemiańskiej i w IPS-ie, w młodzieżowym Klubie Artystycznym „S”, w teatrze, odwiedzając znajomych, przyjmując gości i przyjaciół u siebie. A także: „Telefony, listy, telefony". Pobieżnie dokonany rachunek pozwala stwierdzić, że stosunek liczbowy kobiet do mężczyzn, z którymi kontaktowała się w tym czasie, wynosi mniej więcej 1:3 - na około 60 nazwisk męskich przypada tu niespełna 20 kobiecych, przy czym te ostatnie niekiedy są identyfikowane przez męską atrybucję, np. „jest też Leśmian z córką”, „minister Hubicki z żoną, też piszącą”. Przestrzeń oficjalną zaludniali niemal wyłącznie mężczyźni, kobietom przypadło działanie w przestrzeni prywatnej, jak w domu u Heleny Boguszewskiej, gdzie spotykali się członkowie grupy „Przedmieście”.

W owym dwutygodniowym epizodzie odnotowanym w dzienniku uwidacznia się z całą wyrazistością niezwykłość, wyjątkowość roli, jaką w kulturze dwudziestolecia międzywojennego przyszło odegrać Zofii Nałkowskiej. Autorka Grani$c y$ swobodnie przekraczała większość granic, jakie przebiegały przez ówczesne środowisko literackie. Z salonów i urzędów władzy przemieszczała się w obszary, gdzie toczyło się alternatywne lub wręcz opozycyjne życie literatury, a wszędzie była po trosze u siebie. W częstych pisarskich podróżach odwiedzała euro-

I6 Ibidem, s. 262. 
pejskie stolice i prowincjonalne miasta Polski. W jej najbliższej przestrzeni życiowej przecinały się drogi wszystkich, którzy znaczyli cokolwiek w literaturze, kulturze i życiu publicznym międzywojnia. Jednak tym, co uderza podczas lektury diariusza z lat 1930-1939, jest narastające z roku na rok poczucie kryzysu i schyłkowości w wymiarze prywatnym i zbiorowym. Starzeniu się Nałkowskiej, jej coraz silniej odczuwanemu zmęczeniu i zwątpieniu w wartość własnego pisarstwa, akompaniuje definitywne rozpadanie się porządku w Polsce i w Europie. Ostatni przedwojenny zapis, z 22 sierpnia 1939 r., sporządzony w Adamowiznie u Zofii Zahrtowej, mówi o fatalnym samopoczuciu fizycznym pisarki związanym z „napaściami” na nią Kuczyńskiego. „Zawsze jednak myślę, że gdybym była inna - daleko silniejsza, zdrowsza i może lepsza - to bym wytrzymała" ${ }^{17}$. Następne miesiące i lata miały pokazać, jak wiele była jeszcze w stanie wytrzymać.

\section{EWA KRASKOWSKA}

\section{Alone among Men. Zofia Nałkowska as an Institution of Literary Life in Inter-War Poland.}

The article presents the role of Zofia Nałkowska in inter-war Polish literary culture. Her activity in the structures of literary life was combined with personal commitment to promotion of young talented authors. While she maintained close bonds with the political elites of the Polish Republic, she also functioned above the ideological divisions, actively supporting authors who were opposed the state. As the only woman she was member of the Polish Academy of Literature. Her participation in the official forms of public life forced her to spend time mostly in male company. At the same time, Nałkowska's most important relationships, both with women and men, developed in private space.

Keywords: Zofia Nałkowska, inter-war period, literary life, Polish Academy of Literature.

Ewa Kraskowska - profesor zwyczajny w Instytucie Filologii Polskiej UAM, kierowniczka Zakładu Literatury XX Wieku, Teorii Literatury i Sztuki Przekładu. Badaczka pisarstwa kobiecego i problemów przekładu literackiego. Opublikowała książki: Twórczość Stefana Themersona - dwujęzyczność a literatura (1989), Zofia Natkowska (1999), Piórem niewieścim. Z zagadnień prozy kobiecej dwordziestolecia międzywojennego (1999, 2003), Siostry Brontë (2006), Czytelnik jako kobieta. Wokót literatury i teorii (Poznań 2007). Współredaktorka (z Lucyną Marzec) i współautorka Wielkopolskiego alfabetu pisarek (2012).

${ }_{17}$ Z. Nałkowska, Dzienniki IV 1930-1939. Czessć II (1935-1939), s. 426. 